\title{
The Impact of Voting Trust System on Corporate World and Its Significance for China \& Its Economy
}

\author{
Ali Raza Ansari", Alexandra Jane Davis, Kashif Imran Zadi \\ Guanghua Law School, Zhejiang University, Hangzhou, China \\ Email address: \\ ara_7@live.com (A. R. Ansari), alexd@buryco.com (A. J. Davis), Kashifimran001@hotmail.com (K. I. Zadi) \\ ${ }^{*}$ Corresponding author
}

\section{To cite this article:}

Ali Raza Ansari, Alexandra Jane Davis, Kashif Imran Zadi. The Impact of Voting Trust System on Corporate World and Its Significance for China \& Its Economy. International Journal of Business and Economics Research. Vol. 9, No. 4, 2020, pp. $282-287$.

doi: 10.11648/j.ijber.20200904.25

Received: July 18, 2020; Accepted: August 12, 2020; Published: August 19, 2020

\begin{abstract}
Shareholder voting trusts have had a huge impact on the world as an important device for the protection of shareholders and corporations alike. However, this instrument is missing in the corporate sector of China - one of the world's leading economies. In Part 1, this paper looks at the history of voting trust systems and the path toward legality. Historically, voting trusts were challenged by corporations and majority shareholders before the Court realized the public benefits of shareholder trust agreements. Part 2 uses examples of voting trust systems in other countries to demonstrate its necessity for the well-being of China's corporate system. On the one hand, voting trusts are required for the protection and faith of shareholders and their participation in the market. One of the biggest threats to public participation in investment is lack of protection for minority shareholders. On the other hand, as a corporate safeguard, voting trusts provide an avenue for minority shareholder voices to be heard and prevent corporate dissolution resulting from majority shareholder activism or hostile takeover. Consequently, for China to reach its ultimate goal of becoming the world's largest economy and "Made in China 2025," establishment of a voting trust system within the Chinese corporate sector is essential.
\end{abstract}

Keywords: Voting Trust, Minority Shareholders Rights, Corporate Law, Chinese Economy

\section{Introduction}

The voting trust system has been considered as one of the most important things invented in the corporate world. The word 'trust' used in this perspective was initially defined by the prominent jurist William W. Cook in his treatise called "Stock and Stockholders Under sec. (503)". In it, he defines a trust as an agreement between numerous stockholders who thereby put their stock - and votes resulting from the holding of such stock - into the hands of a trustee and in return receive trust certificates signifying the placement of such trust and the capability to reclaim their stocks [1]. Looking through the pages of history, it seems that Wisconsin's Central Railway trust emerged as the first main voting trust. Under Wisconsin's trust, the railway lines were transferred to a trustee who was authorized to execute full powers in favor of the shareholders in the trust including the right to appoint his successor; however, the shareholders still held a check on the trustee in that a majority of the certificate holders could always object to the actions of the trustee or withdraw from his representation [1]. Though the banded efforts undoubtedly benefitted the shareholders, the main reason behind the establishment of the voting trust system was to help corporations in maintaining the decorum and an element of continuity in the voting process [2]. It has been observed in the past that, the entire direction of a company could be reshuffled if certain officials were changed from their positions it is quite understandable that such change in the top management would impact the whole corporation. Therefore, it is important to have some platform that could provide preventive measures to protect the shareholders during any such incident by accumulating their power under one person who is able to keep an eye on the management and any aggression on their part [2]. 


\subsection{Advantages of Voting Trust in Addition to Shareholder Protection}

There are several effective usages of the voting trust system in instances of corporate restructuring. It has been noticed in a number of cases that when a company reestablishes its business after facing insolvency the incumbent creditors are often found reluctant to advance money without having any surety. Under that condition the corporation is left with two options - either it gives surety by transferring the shares to the creditors, or it transfers the same in the name of a trustee who has been nominated by the creditors under a trust agreement [2]. Under the first option, the corporation must deal with a large number of people and desires - a cumbersome and lengthy process. Under the second, condition the corporation negotiates with one person to come to a reasonable agreement for all involved resulting in faster progress and payback. Hence, a voting trust is one of the most important devices of the corporate world as it facilitates and keeps in pace the corporation's reimbursement of loan payments to creditors as well as preventing any foreign intrusion from taking charge of the company all while protecting the interest of the minority shareholders [2].

\subsection{Positive Impact of Voting Trust Systems on Corporations}

The impact of voting trust on the corporation is of great importance but for the better understanding of the same we must look to what 'trust' means in the modern world. The word 'trust' here means a fiduciary relationship under which one party, known as a trustor, gives another party, known as the trustee, the right to hold title to their shares - and the right associated thereunder - for the benefit of the trustor. In other words, a voting trust is simply a device through which the stock and voting power of each stock holder is put into the hands of trustee so that a corporation shall be governed accordingly without the obligation of taking assent from each shareholder one by one. The trusts are established to provide legal protection for the trustor's assets, to make sure that those assets are distributed according to the wishes of the trustor, and that time is saved - through a reduction of formalities, such as less paper work [1]. One of the best examples of a voting trust can be seen in the shape of Wisconsin Central Voting trust system under which the majority of stock in the rail line called the Wisconsin Central Association was transferred into the name of trustee who became invested with its absolute title including the right to vote on the stock as its legal owner [1]. It has been proven in the past that, one of the best ways for the continuous progress and control of a corporation can only be achieved through voting trust [3].

\subsection{Types of Shareholder Voting Systems}

The corporate world has several types of voting systems that are used for the purpose of voting by shareholders. However, the few most commonly practiced types throughout the world are as follows: (1) statutory voting system; (2) cumulative voting; and, (3) proxy voting. A statutory voting system sometimes referred to as straight voting - is a kind of voting system under which every shareholder is only entitled to one vote and the votes must be equally divided among all the candidates [4]. Cumulative voting is a kind of voting procedure under which the shareholders at the time of electing a company's director are entitled to one vote per share multiplied by the number of directors that are to be elected [5]. This type of system is beneficial to the individual investors because they can combine all of their votes into one 'supervote' and cast the same to a single candidate. Whereas, Proxy voting is a kind of voting under which a vote is cast either by an elected person or firm on behalf of a shareholder due the shareholder's absence - in other words, proxy voting is the delegating of one's authority to another [6]. The absence could be due to the fact that either the shareholder is unavailable such as when a shareholder is busy or lives far away from the corporation - or simply has no desire to attend the shareholder meeting. This type of system is frequently practiced in the United States, specifically by investment or financial advisors who cast votes on behalf of their clients [6].

\subsection{The Effect of Voting Trusts on Shareholders}

Voting trusts impact shareholders in number of ways; whenever shareholders are free to accumulate their power together into one specific person who can cast a vote on their behalf, a shareholder with a small number of votes effectively multiplies its own power in import decisionmaking processes by those with whom he joins. Such act of joining together naturally brings positive results and a certain edge over the corporation to the stockholders who were scattered and individually weak before the existence of a voting trust system. It is due to this fact that after the inclusion of a voting trust system into a corporation, these previously powerless shareholders are now able to nominate several directors and other persons holding numerous important positions in the corporations [7]. It would not be wrong to say that the voting trust is mainly a device used to provide relief and protection for minority shareholders against the aggression of majority shareholders while simultaneously providing the ability to take charge of the corporation into their hands. Courts in the past have discredited minority shareholders from attaining the entire control over a corporation on the ground that the control and management basically belongs to the major shareholders [810]. However, on the contrary, these courts are also found acknowledging the fact that the minority shareholders are required to be secured and protected; it is understandable that they need a system like voting trust through which their interests could be served. Therefore, the placement of a voting trust system needs to have some proper justification for claiming such benefit and it should be assured that the same would also benefit the company too. Such act should not affect the interest of other shareholders and only under this condition shall the trust be deemed justified [11-14]. However, if it appears that the joinder of shareholders reflects any wrong intention which might cause harm for the 
corporation and is only created for gaining personal benefits without considering the interest of other shareholders, then under such scenario the trust shall be considered as unlawful $[13,14]$. In several judgements the courts have found in favor of voting trusts as an appropriate mechanism because it is by this way the minority shareholders could work as a watch dog in the corporation [11-13].

\section{Classification of Voting Trusts and Their Different Operations}

Voting Trusts are classified in two different ways: (1) those not involving minority control; and, (2) those affecting minority interests. It is not always necessary that the voting trust only provide benefits to minority shareholders. In a number of cases, it has been recognized by the courts that even when there is no consideration of minority protection, the court considers voting trusts as valid when it serves in the best interest of a corporation's creditors [14]. On this premise, the voting trust shall be deemed valid if it operates for the sake of raising capital for the corporation and if the same has been created for the purpose of paying off debt [15]. With regard to voting trusts affecting minority control, a very famous case decided by the California Supreme Court in 1897 - Smith v San Francisco \& N. P. Ry. This case has been used as a reference in the past for the validation of voting trust under several other voting trust court cases. In it, the plaintiff entered in to contract with two people and bought stock in a corporation in bulk quantity; it was then agreed upon that the votes in the corporation would be casted by the majority of the trust for a five year duration and the voting power would only be in the hands of majority even if they sold the stock [16]. However, the plaintiff rescinded the agreement and claimed his voting right as the corporation's stockholder. The corporation denied such voting right in its elections and when his request was declined the plaintiff decided to approach the court with a plea that his separate voting right should be considered and that the court should force the corporation to allow him to vote. The court, however, declined the request on the ground that the agreement was legal and did not affect the interest of corporation as there was no illegality on the surface of the agreement [16]. Thus, it can be seen that while courts uphold voting trusts to protect minority shareholder interests, it will not invalidate the trust simply because a few of those banded together decide to break away from it.

\subsection{Evidence of Voting Trust Advantages to Corporations from the Past}

The voting trust is an important way through which so many problems could be addressed in corporations. Whenever there is a hostile takeover condition and the corporation issues new shares and older shares are purchased up by the acquirer for the purpose of attaining hold over the company, the shareholders may secure themselves by establishing a voting trust. Hence, through this way, the shareholders attain such power which prevents them from being abused by the new company. The voting trusts allows the shareholders to lift older shares from the "open market" which means that the hostile acquirer is left with only one option which is to buy the non-voting certificates from the market [17]. It has been noticed on several occasions that voting trusts have provided breathing space for corporations specifically during periods of crises when corporations are on the verge of insolvency and the creditors have pumped huge amount of money into the company in return for its command. Hence, it is a clear indication of how beneficial this instrument is for the purpose of securing the business of the company even under the condition of severe economic distress [18].

\subsection{Positive Impressions of Voting Trust on Other Corporate Systems}

There are several corporate systems in the world which have prospered because of the voting trust system or to a similar kind of system with a different name. For instance, in the corporate governance of France there is a system called as Syndicats-de-Blocage under which voting rights are transferred to the heads of syndicates/organizations who act and vote on behalf of all the shareholders [19]. Moreover, many countries - such as Canada and the Philippines ${ }^{1}[20]$ have acknowledged the legitimacy of shareholder voting trusts by allowing for shareholder trust agreements. Finally, Japan has implemented a voting trust system that triggers specifically in hostile takeover situations [21]. Under this system, a company offers a plan to shareholders whereby the issuance of share options by the company go to a special purpose company (SPC) [21]. Subsequently, one of two things can happen - the SPC can then establish a trust as the settlor of shares, or it can utilize a direct trust method "whereby the issuing company directly issues the share options to the trust" [21]. Under either system, when a hostile buyer emerges, share options are issued to all shareholders other than the hostile buyer, and the percentage of voting rights held by the hostile buyer is reduced by exercising such share options. Thus, it can be seen that voting trusts are an accepted practice across the world.

\subsection{Voting Trust a Much Safer Medium than Proxy}

There is always a confusion as to whether trust is a kind of proxy or is it entirely a different thing. For some people, it is hard to differentiate between a trust and a proxy as they consider a trust as a type of proxy. Such confusion is reasonable since they involve the transfer of shareholders' authority to vote into another person who could vote on their behalf. However, the difference between a proxy and a trust is that in proxy the right to vote is transferred for a very limited time while in the case of a trust the right to vote is transferred for a much longer period; similarly, the proxy

1 Section 59 of the Corporation Code of The Philippines provides for the establishment of a voting trust agreement not exceeding five years duration. 
may be created for some particular vote while the trust is more permanent in nature [22]. There are some conditions under which the shareholder often opts to go for the proxy option specifically when he or she does not feel the need to attend a particular vote; they can delegate the authority to someone in attendance that shares the same views as themselves. Meanwhile, in the voting trust when several shareholders delegates their voting right by a trust agreement into another person for the purpose of voting on their behalf for an extended period of time then such act is known as trust. The basic reason for voting trust is to make a band of fragile or vulnerable shareholders through which they could block any move that could adversely affect their interest [22]. In simple words we can say that a proxy is basically an agent which could be revoked at any time but on the other side, the trustee is not an agent but he is actually the holder of the title coupled with the powers to manage the affairs of the corporation in the execution of its duties as a trustee [23]. As a trustee, however, the person has a fiduciary relationship to the shareholders he represents and thus can be held accountable for the voting transactions unlike a proxy. Thus, transferring votes in a trust allows for better accountability for the actions of the voter.

\subsection{Why a Voting Trust System Is Important for China}

The importance of voting trust in China is paramount because China is the world's greatest rising power. Therefore, it is necessary that along with other developed countries it also have the system of shareholders voting trust. In today's modern world, a system of shareholder voting trusts plays a very important role in the corporate sector as minority shareholders are often ignored by the majority shareholders which leads to uncertainty and hesitance of public participation in investment opportunities. To overcome this lacuna, it is of utmost importance for China to propose a system through which the minority shareholders and their interests are effectively considered. The voting trust system does not only bring benefits to shareholders but it is also provides benefits to the entire corporation due to the phenomenon of joint voting. Whenever a resolution is adopted it naturally becomes binding upon all of the shareholders due to the voting trust system and therefore, all of the shareholders are obligated to accept such resolution and joint venture. Article 4 of the Company Law of China also provides that the shareholder of the company shall be entitled to enjoy capital proceeds, and shall participate in making important decisions, choose managers and enjoy other respective rights. Similarly, for the purpose of making these rights practical, it is very much necessary that a voting trust system should be adopted in China so that the rights of shareholders including the minority holders can be protected in accordance with its Company Law [24].

\subsection{Way Towards Permanent Corporate Solution}

The aforementioned study clearly suggests the importance of the voting trust system as it provides opportunity for representation of all shareholders in a corporation. As numerous corporations go through an annual election process, it is probable that voting trust systems would directly impact corporate control of the shareholders in a positive way. Without such a system in place, there is a very high chance that the major policies of the corporation are only to benefit a single majority shareholder without consideration of the company as a whole or opportunities that could be explored. Thus, to curb these mentioned issues it is paramount that a voting trust system should be introduced in the corporate system to allow for continued growth [2]. This benefits the nation's corporations because it allows for opportunity and financial backing for exploratory avenues to grow or change company progress that may otherwise be quashed by a leery majority shareholder. Furthermore, the system provides confidence for the minority shareholders to participate in corporate decision-making as they can use their power of vote alongside the majority [25].

\subsection{Probable Benefits of Voting Trust for Chinese Economy}

The Chinese economy has witnessed constant growth in recent years [26] and has provided massive benefits to numerous economies of world since it initiated to open-up its doors. Simultaneously, the same phenomenon has benefited numerous multinational corporations [27]. Likewise, the prime target of present Chinese regime is focused on making Chinese economy into world leading economy. As, the "Made in China 2025" program is based on same approach as it targets to avoid the "middle-income trap" which normally impacts numerous counties with lower income growth [28] However, for achieving the ultimate result of success of Made in China 2025 program the Chinese government is constantly promoting investment in its stock market [29] It is true that, the shareholder protection is still a major concern in China therefore, the Supreme People's Court of China seems pretty active in this regard, as it has promulgated several provisions regarding the matter [30]. Which is a viable proof that, protecting bodies such as voting trust is very much necessary [17] as it would ultimately benefit the entire Chinese corporate system the target of which is to achieve its prime object which is to turn made in China 2025 concept into reality [27].

\section{Conclusion}

It is obvious from the above deliberation that voting trust system has been emerged as one of the most important devices of the corporate system. Despite having massive opposition, it has flourished over the years and has managed to establish its legal status not only in the eyes of corporate entities but even in the eyes of the courts of justice. Its existence today is significant proof that progress can overcome all of the troubling weathers of the past. Hence, in China's case it will be an important step as the country progresses to such status never before attained in the modern world. Therefore, China's adoption of a voting trust system is 
an ideal step towards security of the current corporate system and more active participation from the general class in investment within its borders which would also put positive impact on the Chinese economy. Therefore, as it is previously observed, when a country's citizens feel confident in investing in a country's market, then fruitful results are close on the horizon. With a country whose citizens already demonstrate such nationalism and desire to move forward, a voting trust system in China could make its progress unstoppable on economic front.

\section{References}

[1] Leroy Horton, "Voting Trusts in Corporations", CORNELL, Historical Theses and Dissertations Collection, Paper 357, (1896) available

https://scholarship.law.cornell.edu/cgi/viewcontent.cgi?article $=1343 \&$ context $=$ historical_theses.

[2] Wanda Bartos, "Uses of The Voting Trust" 34: 2 N.Y. U. L. REV., 290-303 (1959) available at https://heinonline.org/HOL/Page?public=true\&handle=hein.jo urnals $/$ nylr34\&div $=25 \&$ start_page $=290 \&$ collection $=$ journals \&set_as_cursor $=4 \&$ men_tab $=$ srchresults

[3] Arthur Stone Dewing, Financial Policy of Corporations (3) (1934) available https://heinonline.org/HOL/Page?public=true \&handle=hein.be al/fnlpcor0001\&div=21\&start_page $=386 \&$ collection=beal\&se t_as_cursor $=2 \&$ men_tab $=$ srchresults

[4] Marshall Hargrave, "Statutory Voting", Investopedia (Aug. 29, 2019) available

https://www.investopedia.com/terms/s/statutoryvoting.asp.

[5] James Chen, "Cumulative Voting", Investopedia (Apr. 30, 2019) available at https://www.investopedia.com/terms/c/cumulativevoting.asp.

[6] Will Kenton, "Proxy Vote", Investopedia (Jun. 27, 2018) available at https://www.investopedia.com/terms/p/proxyvote.asp.

[7] "Quotation Southern Railway Voting Trust Extension Circular", 393 n. (h).

[8] English v. Rosenkrantz, 152 Ga. 726, 111 S. E. 198 (1922) available https://heinonline.org/HOL/CaseLaw? 1=1\&native_id=784410 $3 \&$ cop $=1 \&$ collection $=$ journals.

[9] Morel v. Hoge, 130 Ga. 625, 61 S. E 487 (1908) available at https://heinonline.org/HOL/CaseLaw? $1=1$ \&native_id $=755233$ $5 \&$ cop $=1 \&$ collection $=$ journals.

[10] Luthy v. Ream, 270 III.170, 110 N. E 375 (1915) available at https://heinonline.org/HOL/CaseLaw? $1=1$ \&native_id $=950283$ $0 \&$ cop $=1 \&$ collection=journals.

[11] Mackin V. Nickollet Hotel, Inc., 25 F.2d 783 (8th cir.), cert denied 278 U.S 618 (1928).

[12] V. Kentucky Ref. Co., 144 Ky. 264, 138 S. W. 264 (1911).

[13] Bowditch v. Jackson Co., 76 N. H.351, 360, 82 Atl. 1014, 1019 (1912).
[14] Boyer v. Nesbitt, 227 P. A. 398, 76 Atl. 103 (1910).

[15] Milton M. Bergerman, "Voting Trust and Non-Voting Stock" YALE L. J. 445, 454 available at https://digitalcommons.law.yale.edu/cgi/viewcontent.cgi?refer er $=\&$ httpsredir $=1 \&$ article $=3268 \&$ context $=y l j$.

[16] Smith v. San Francisco \& N. P. Ry., 115 Cal. 584, 47 PAC 582 (1897).

[17] Henry. W. Ballantine, "Voting Trusts, Their Abuses and Regulation," 21 TAX L. REV. 139, 153 (1942) available at https://heinonline.org/HOL/Page?handle=hein.journals/tlr21\& page $=139 \&$ collection $=$ journals.

[18] Robert W. Miller, "Voting Trusts." 4: 9 INDIANA L. J. 600, 600-07, (June 1929) available at Hein Online, https://heinonline.org/HOL/P?h=hein.journals/indana4\&i=612.

[19] Carl Martin Ross, "Comparative Note on Shareholders Voting Agreement", 15 SCANDINAVIAN STUDIES IN LAW, 163190 (1971) available at https://heinonline.org/HOL/Page?handle=hein.intyb/svns1001 $5 \&$ id $=163 \&$ collection $=$ intyb\&index $=$.

[20] Corporation Code of The Philippines, Sec 59.

[21] "Trust-Type Rights Plan", Trust Companies Association of Japan (2020) available at https://www.shintakukyokai.or.jp/en/trusts/trusts03_14_10.html.

[22] Erika Johansen, "Voting Trust VS. Voting Proxy", ZACKS (accessed 19 Feb. 2019) available at https://finance.zacks.com/voting-trust-vs-voting-proxy7370.html.

[23] Voting Trust and Holding Companies", 3: 3 YALE L. J. 109123 (1904) available at https://www.jstor.org/stable/783089?Search=yes\&resultItemC lick=true\&searchText=corporation\&searchText=voting\&searc hText=trust\&searchText=revocation\&searchUri $=\% 2$ Faction $\%$ 2FdoBasicSearch\%3FQuery\%3Dcorporation\%2Bvoting\%2Bt rust $\% 2$ Brevocation\&ab segments $=0 \% 2 \mathrm{Fbasic}$ SYC$4341 \% 2$ Fcontrol\&refreqid=search $\% 3 \mathrm{Aa} 394 \mathrm{~d} 99 \mathrm{e} 2235 \mathrm{fcd} 69 \mathrm{db}$ 1de73f026a10e\&seq=1\#metadata_info_tab_contents.

[24] Article 4, Company Law of China available at http://awinfochina.com/display.aspx?id=e797dd968c30e172b dfb\&lib=law.

[25] Graham Topa \& Amy Marcen Gaudaur, "Voting Trusts: Think Ahead", MONDAQ (Mar. 13, 2017) available at http://www.mondaq.com/canada/x/576308/Corporate+Comme rcial+Law/Voting+Trusts+Think+Ahead.

[26] Nick Leung, "China Brief: The State of the Economy", MCKINSEY \& CO. (Mar. 2019), available at https://www.mckinsey.com/featured-insights/china/chinabrief-the-state-of-the-economy.

[27] Jonathan Woetzel, et al., China and the World, MCKINSEY GLOBAL INST. (2019) available at https://www.mckinsey.com/ /media/mckinsey/featured\%20ins ights/china/china $\% 20$ and $\% 20$ the $\% 20$ world $\% 20$ inside $\% 20$ the $\% 20$ dynamics $\% 20$ of $\% 20 \mathrm{a} \% 20$ changing $\% 20$ relationship/mgichina-and-the-world-full-report-june-2019-vf.ashx.

[28] Wayne M. Morrison, "The Made in China 2025 Initiative: Economic Implications for the United States", CONG. RES. SERV., Paper No. IF10964 (2019) available at https://fas.org/sgp/crs/row/IF10964.pdf. 
[29] Kimberly Amadeo, “China's Economic Growth, Its Causes, Pros, Cons and Future" (2019) available at https://www.thebalance.com/china-s-economic-growth-causepros-cons-future-3305478.
[30] China Business: Protecting Your Corporate Rights as a Shareholders (2019) available at https://www.thesquare.blog/2019/08/06/china-businessprotecting-your-corporate-rights-as-a-shareholder/. 